\title{
KREATIVITAS NETIZEN DALAM STRATEGI PEMASARAN \\ RESTORAN UNTUK MENARIK WISATAWAN \\ (STUDI KASUS RESTORAN HOTEL BEST WESTERN \\ PREMIER LA GRANDE BANDUNG)
}

\author{
Murdiani Sukarana \\ Prodi Manajemen Tata Hidang Politeknik Pariwisata Makassar \\ Email: anhiesukarana@gmail.com \\ Muhammad Anas \\ Prodi Manajemen Tata Boga Politeknik Pariwisata Makassar \\ Email: mail.nazta@gmail.com
}

\begin{abstract}
The aim of this research is to explain the role of hotels in promoting their restaurants and create new ideas on the resources owned by hotels to develop marketing techniques with digital and contemporary channels. The research was conducted at the Restaurant Best Western Premiere La Grande Bandung. This research is a qualitative research with data and analysis results presented in the form of descriptions through observation methods, in-dept interviews, and documentation. Data analysis technique with steps; data processing, data analysis, and interpretation of data analysis results. The result of this research is that marketing media through the internet (digital promotion) has a very significant effect on visitors to the Best Western Premiere La Grande Hotel Restaurant, Bandung. Among the online media used by restaurant management, Instagram has the greatest impact on promotional results to visitors. Consecutively the role of digital media in marketing results, namely $45 \%$ of the Instagram hashtag, $32 \%$ of the website and $23 \%$ of the e-brochure. Thus the digital marketing strategy has a high level of effectiveness in introducing hotels in general and specifically at the Restaurant Hotel Best Western La Grande Bandung.
\end{abstract}

Keywords: marketing strategy, creativity, netizen

\section{Pendahuluan}

Industri pariwisata saat ini menjadi angin segar bagi pertumbuhan ekonomi nasional (Noviantoro \& Zurohman, 2020). Pariwisata menjadi bidang yang diunggulkan dalam menyumbang devisa negara. Melalui laman resmi 
kemenpar.go.id pada Siaran Pers Komblik /21/10/2018 dinyatakan bahwa sektor pariwisata mengalami tren positif selama empat tahun berjalan pemerintahan JokowiYusuf Kalla. Sektor tersebut mengalami peningkatan sangat pesat, karena menghasilkan banyak devisa sehingga pemerintah antusias menyambutnya melalui program yang dicanangkan pada tahun 2019. Kini telah memasuki tahun 2020, upaya dan strategi dalam pengembangan sektor pariwisata terus ditingkatkan serta secara continue mencari strategi baru demi mewujudkan pariwisata sebagai primadona penyumbang devisa negara.

Industri pariwisata memiliki prospek dan perkembangan yang sangat baik di era global. Sejak era milenium baru hingga memasuki era digital, industri ini semakin melesat perkembangannya (Utama \& SE, 2015). Calon wisatawan cukup hanya bermodalkan smart phone maka sudah bisa dengan mudah berencana dan melakukan kunjungan wisata sesuai keinginan. Melalui perkembangan pariwisata, banyak juga industri-industri pendukung yang tumbuh pesat dalam menyokong penyedia jasa pada objek wisata yang ada.

Beberapa tahun terakhir, banyak negara di dunia melakukan pembangunan dengan berorientasi pada pengembangan sektor industri dan jasa. Termasuk yang paling banyak menjadi program utama yakni pengembangan industri pariwisata. Pariwisata menjadi primadona baru dalam menyokong perekonomian masyarakat dunia. Dalam hasil penelitian tentang pariwisata dan pengentasan kemiskinan dinyatakan bahwa Industri pariwisata merupakan salah satu roda penggerak ekonomi masyarakat. Melalui Industri Pariwisata, peluang usaha terbuka lebar dan potensi lapangan pekerjaan yang tersedia juga semakin besar (Moenir, 2017). Keadaan ini semestinya menjadi titik balik bagi pelaku industri dan penyedia jasa pendukung sektor pariwisata sebagai peluang dalam mengembangkan usaha. Karena hal tersebut sangat potensial untuk dapat berkembang bersama industri pariwisata. Diantaranya 
yaitu usaha perhotelan, restoran, SPA, kuliner, pusat oleh-oleh dan sebagainya. Namun demikian, perlu strategi khusus untuk menarik minat pengunjung.

Pada tahun 2018 sektor pariwisata Indonesia mengalami peningkatan yang pesat dan memberikan sumbangsih capaian sekitar $18 \%$ bagi devisa negara. Tidak salah jika pada tahun-tahun berikutnya Kementerian Pariwisata menargetkan sekitar 25\% atau setara 5 juta dari angka capaian tahun sebelumnya (Noviantoro \& Zurohman, 2020). Termasuk beberapa kota besar di Indonesia yang memproyeksikan pariwisata ke dalam sektor unggulan. Salah satunya adalah kota Bandung. Keadaan morfologi dan tipologi unik serta budaya khas yang dimiliki kota Bandung menjadikannya banyak dikunjungi pelancong. Di samping icon paris van java, Bandung juga terkenal mempunyai banyak destinasi wisata, misalnya kawah putih, tangkuban perahu, pemandian air panas Cimanggu dan masih banyak yang lainnya. Daya tarik inilah yang menjadikan kota Bandung banyak dikunjungi wisatawan (Sukriah, 2014).

Berkembangnya pariwisata sebagai sektor unggulan di kota Bandung otomatis juga akan berpengaruh terhadap sektor industri jasa yang lain. Salah satu yang paling banyak viral di media sosial internet dan cukup menarik untuk diulas adalah keberadaan Hotel Best Western Premier La Grande. Hotel ini termasuk dalam kategori hotel berbintang yang banyak diminati golongan menengah ke atas, sehingga termasuk kelas premium.

Best Western Premier La Grande merupakan sebuah rumah penginapan (hotel) di kota Bandung. Hotel ini termasuk kategori berbintang sehingga terdapat beberapa fasilitas yang melingkupinya. Diantara fasilitas yang ada, terdapat fasilitas rumah makan (restoran) yang menjadi fasilitas unggulan. Dengan demikian, keberadaan restoran pada hotel tersebut secara otomatis juga merupakan salah satu sumber pendapatannya. 
Permasalahan yang kerap terjadi di ruang lingkup restoran hotel yaitu pemasaran. Dalam hal ini biasanya restoran hotel masih sering menginduk di dalam hotel baik manajemen dan pemasaranya. Pemasaran hotel masih didominasi fasilitas pokok misalnya kamar dan meeting room, sehingga pemasaran restoran kurang optimal. Hal ini berdampak pada pendapatan restoran yang kurang memenuhi target. Oleh karenanya, tujuan dari penelitian ini yakni untuk memaparkan tentang bagaimana peran hotel dalam mempromosikan restorannya. Selain itu, melalui penelitian ini dapat menciptakan terobosan strategi baru pada human kreatif hotel guna menyusun teknik pemasaran melalui kanal digital dan kekinian. Terutama ditujukan kepada para segenap pengunjung objek wisata (wisatawan) di Bandung.

Perkembangan teknologi yang sangat cepat membuat banyak orang telah merubah pola perilakunya menjadi digital minded dan mobile-first preferred. Aspek inilah yang harus diperhatikan oleh pelaku usaha jasa termasuk pihak pengelola restoran hotel. Oleh karenanya pemanfaatan TIK berbasis digital harus dilakukan secara aman guna mengantisipasi terjadinya penyalahgunaan. Atas dasar tersebut diterbitkan UU ITE yang berisi tentang aturan pemasaran melalui kanal digital serta Undang-Undang Nomor 8 Tahun 1999 tentang Perlindungan Konsumen (UU PK). Artinya pemanfaatan strategi pemasaran digital yang dilakukan human kreatif dilindungi pemerintah melalui undang-undang.

\section{Metode Penelitian}

Metode yang digunakan dalam penelitian ini adalah deskriptif kualitatif. Menurut Ratna penelitian dengan metode kualitatif pada akhirnya akan menghasilkan data deskriptif dalam bentuk kata-kata. Hasilnya dapat berupa tulisan atau pun lisan. Lebih jauh lagi, Ratna juga mengungkapkan bahwa dalam penelitian kualitatif yang terpenting adalah menemukan makna yang terkandung di dalamnya (Ratna, 2019). 
Adapun data yang digunakan dalam penelitian yakni data primer dan data sekunder. Data primer adalah seluruh data yang diperoleh di lapangan secara langsung ketika wawancara in-dept dengan pihak Hotel Best Western Premier La Grande Bandung, dokumentasi audio visual, dan catatan observasi yang bersifat participant observation. Sementara data sekunder adalah seluruh data yang didapat melalui berbagai referensi ataupun sumber yang relevan. Data sekunder berupa bahan-bahan studi kepustakaan yang diperoleh melalui dokumen, catatan arsip, hasil publikasi ilmiah yang sesuai dengan topik penelitian serta data dari berbagai dokumen pendukung lainnya.

Teknik pengumpulan data yang digunakan yaitu observasi, wawancara indept, dokumentasi dan study pustaka. Adapun teknik analisis datanya menggunakan analisis deskriptif kualitatif dengan langkah-langkah, yaitu; olah data, analisis, uji validitas melalui teknik triangulasi, dan diakhiri dengan penafsiran hasil analisis data. Teknik triangulasi dimaksudkan agar data-data yang didapat dari berbagai sumber menjadi absah dan valid untuk dijadikan dasar dalam analisis.

\section{Hasil dan Pembahasan}

\section{Strategi Pemasaran Restoran}

Restoran merupakan fasilitas pokok yang akan menunjang kualitas sebuah hotel. Banyak anggapan tingkat kualitas hotel selain kamar juga restoran dengan layanan dan sajian yang ada. Secara historis, restoran atau rumah makan berawal dari restoran-restoran yang berada di hotel dengan pelayanan yang standart. Setelah itu dalam kesempatan tertentu, para juru masak (chef) yang pernah bekerja di restoran hotel mencoba membangun bisnis secara mandiri.

Dalam dunia bisnis, usaha di bidang kuliner cukup menjanjikan. Oleh karenanya sangat menarik untuk dikaji dan ditelaah secara mendalam. Beberapa 
alasan usaha kuliner menjadi primadona saat ini antara lain income profit yang cukup besar, wilayah market yang luas, serta dukungan teknologi yang sudah memadai. Selain itu gaya hidup masa kini yang menganggap restoran merupakan salah satu bentuk lain dari destinasi wisata kuliner.

Perkembangan usaha kuliner dalam hal ini bisnis makanan dan minuman masih cukup massif di berbagai negara (Nonto, 2006). Artinya usaha tersebut masih memiliki bargaining power atau pun daya tawar yang baik untuk meningkatkan perekonomian. Hal itu ditandai dengan mulai banyak menjamurnya outlet baru yang menawarkan berbagai produk makanan ataupun minuman. Bahkan dalam skala yang luas usaha kuliner juga sudah banyak memakai strategy Franchise. Hal ini dapat terjadi karena makan dan minum adalah kebutuhan pokok yang secara pasti harus dipenuhi oleh setiap orang.

Dari pemaparan tersebut jelas bahwa restoran merupakan bisnis yang akan membantu pertumbuhan dan pengembangan hotel. Begitu juga dengan Hotel Best Western Premier La Grande Bandung. Hotel ini menyediakan Restoran bukan hanya menyediakan menu makanan dan minuman untuk pengunjung namun juga untuk mengembangkan profit margin bagi hotel. Hotel Best Western Premier La Grande Bandung memiliki kesadaran bahwa restoran mampu mejadi bisnis tersendiri untuk mendukung kualitas hotel secara keselurahan. Terlebih dengan semakin berkembangnya konsep wisata kuliner. Oleh karena itu hotel tersebut melakukan strategi pemasaran restorannya dengan sangat baik.

Pada hakekatnya strategi pemasaran merupakan segala perencanaan yang terpadu dan menjadi kesatuan dalam konteks pemasaran, memberikan acuan tentang aktivitas yang akan dijalankan untuk mencapai target marketing dalam suatu perusahaan (Assauri, 2011). Di sisi lain pemasaran berarti proses sosial antar personal maupun kelompok dengan tujuan untuk memperoleh apa yang dibutuhkan melalui pertukaran dan penawaran produk atau dapat pula berupa pelayanan atau jasa 
(Kurniullah, 2017). Sedangkan peningkatan omzet penjualan merupakan tujuan utama dalam strategi pemasaran. Dengan kata lain penjualan merupakan ujung tombak dari strategi yang diterapkan sebuah perusahaan. Tentu dalam hal ini bagaimana pemasaran restoran dilakukan untuk mendukung tercapaianya tujuan utama pada kualitas Hotel Best Western Premier La Grande Bandung.

\section{Strategi Pemasaran Digital (online)}

Kegiatan pemasaran tidak cukup hanya dilakukan dengan metode dan strategi konvensional. Dalam perkembangan zaman yang terus maju, kegiatan pemasaran harus berlandaskan kreativitas dan menerapkan teknologi digital yang sedang berkembang saat ini (Usmara, 2008). Tentu ini tidak mengurangi subtansi tentang pemasaran itu sendiri. Strategi pemasaran pada dasarnya merupakan segala perencanaan yang terpadu dan menjadi kesatuan dalam konteks pemasaran, memberikan acuan tentang aktivitas yang akan dijalankan untuk mencapai target marketing dalam suatu perusahaan. Dengan kata lain strategi pemasaran adalah serangkaian perencanaan, kebijakan, dan aturan yang memiliki sasaran/target untuk memberikan panduan arah pemasaran pada perusahaan (Assauri, 2011). Implementasi pemasaran ini salah satunya adalah promosi dan publikasi.

Saat ini teknologi semakin canggih dan berkembang sangat pesat. Inovasiinovasi teknologi yang ada juga semakin beragam. Mulai dari yang sederhana hingga teknologi rumit semua ada mewarnai kehidupan manusia modern. Sejak satu dekade terakhir, salah satu teknologi yang paling berpengaruh adalah internet. Secara sederhana internet merupakan jaringan nirkabel yang dapat menjadi sarana utama komunikasi global melalui koneksi jutaan bahkan milyaran perangkat seperti komputer dan Handphone. Berdasar hasil penelitian, pesatnya perkembangan internet juga dapat mempengaruhi kehidupan sosial dan cara komunikasi seseorang (Pang, 2013). 
Pemanfaatan teknologi inilah yang menjadi Strategi pemasaran yang dilakukan pihak pengelola hotel Best Western Premier La Grande Bandung. Pemasaran dilakukan melalui media digital atau biasa disebut promosi online. Hal ini dapat dilihat dari temuan di lapangan bahwa hotel Best Western Premier Bandung memiliki website online yang beralamat di http://bwpremierlagrande.com/ dan Digital Brochure. Kedua konten ini selain mendukung pemasaran hotel, juga mengenalkan restoran yang dimiliki hotel Best Western Premier Bandung (Humas, personal communication, 2019).

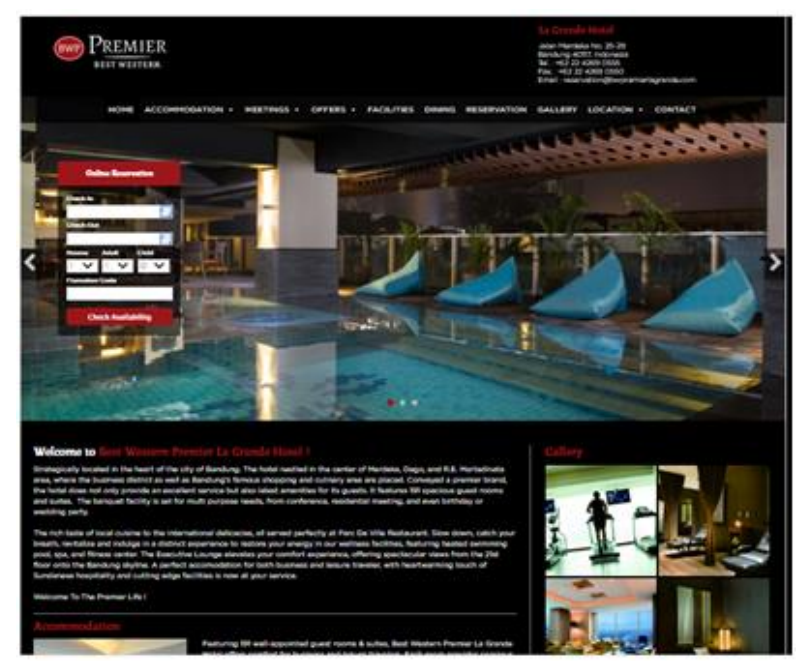

Gambar 1. Bentuk strategi pemasaran online berbasis Website Hotel Best Western Premier Bandung

Sumber: (Best Western Premier La Grande Hotel I Bandung, Indonesia, n.d.) 


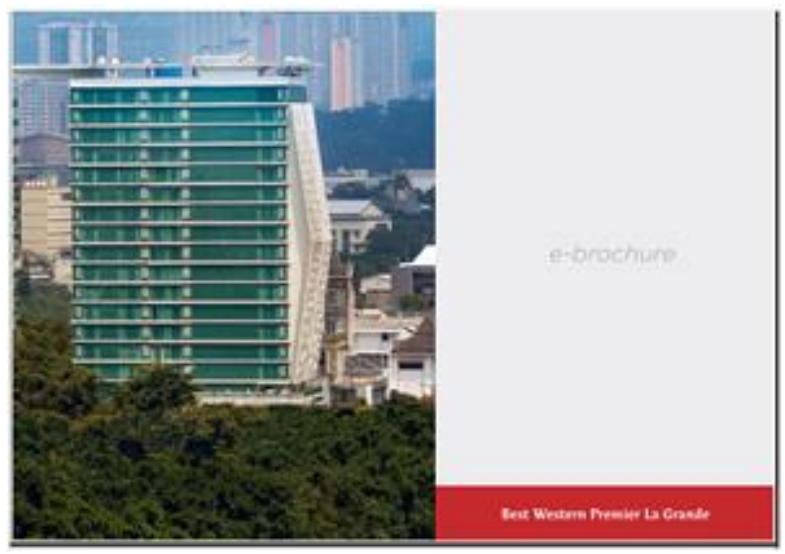

Gambar 2. Bentuk strategi pemasaran online berbasis e-brochure di hotel Best

\section{Western Premier Bandung}

Sumber: (Best Western Premier La Grande Hotel I Bandung, Indonesia, n.d.)

Website online yang berlamat di http://bwpremierlagrande.com/ memiliki page atau halaman khusus untuk konten Restoran yaitu pada page dining. Pada page dining ini berisi foto-foto tentang area restoran dari berbagai sudut dan menu yang tersedia. Di halaman ini pengunjung web dapat diarahkan untuk mengetahui lebih jauh tentang restoran di hotel Best Western Premier Bandung. Pada Page ini juga berisi informasi detail tentang operasional dan pelayanan restoran, sehingga memudahkan akses pemesanan dan juga mampu menjadi strategi pemasaran yang efektif untuk mengenalkan restoran ini pada khalayak yang lebih luas.

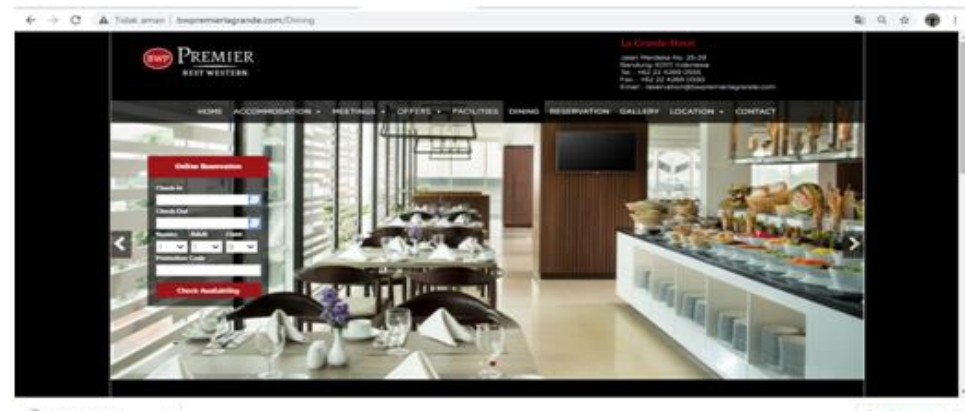

Gambar 3. Tampilan Website http://bwpremierlagrande.com/ pada halaman dining Sumber: (Best Western Premier La Grande Hotel I Bandung, Indonesia, n.d.) 


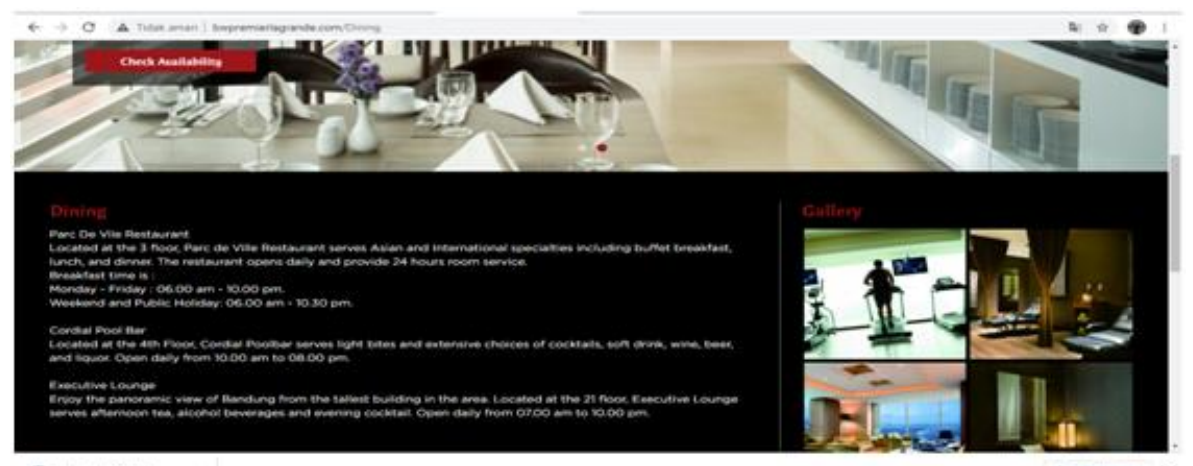

Gambar 4. Tampilan Informasi di Website http://bwpremierlagrande.com/pada halaman dining

Sumber: (Best Western Premier La Grande Hotel I Bandung, Indonesia, n.d.)

Website yang dikelola oleh pihak Hotel Best Western Premier Bandung menjadi salah satu adaptasi pada pemasaran digital berbasis online. Website dirasa sangat informatif terutama pada saat pandemi. Pengelola humas dari pihak hotel dalam wawancara penelitian menyebutkan pemasaran digital melalui website ini cukup membantu untuk mengenalkan hotel dan kesiapan hotel dalam menghadapi pandemic Covid-19 (Humas, personal communication, 2019).

Di luar website tersebut pihak pengelola Hotel Best Western Premier Bandung juga meluncurkan e-brochure yang dapat diakses dan dishare di beberapa media sosial. E-brochure ini selain mengenalkan fasilitas hotel secara luas juga mengenalkan restoran dalam bentuk interior. Kelebihan e-brochure ini adalah kemudahan akses mendapat informasi, sifatnya yang ringan dan mudah untuk dishare di sejumlah media sosial. Meski informasi dalam e-brochure sangat terbatas, namun di sana ditampilkan alamat website dari Hotel Best Western Premier La Grande Bandung, sehingga e-brochure ini terintegrasi dengan website. Pembaca e-brochure yang yang tertarik untuk mengetahui lebih jauh tentang Hotel Best Western Premier La Grande Bandung akan dimudahkan untuk masuk ke website, karena setiap e-brochure pada bagian tamplate bawah dituliskan alamat website berserta barcodenya. 


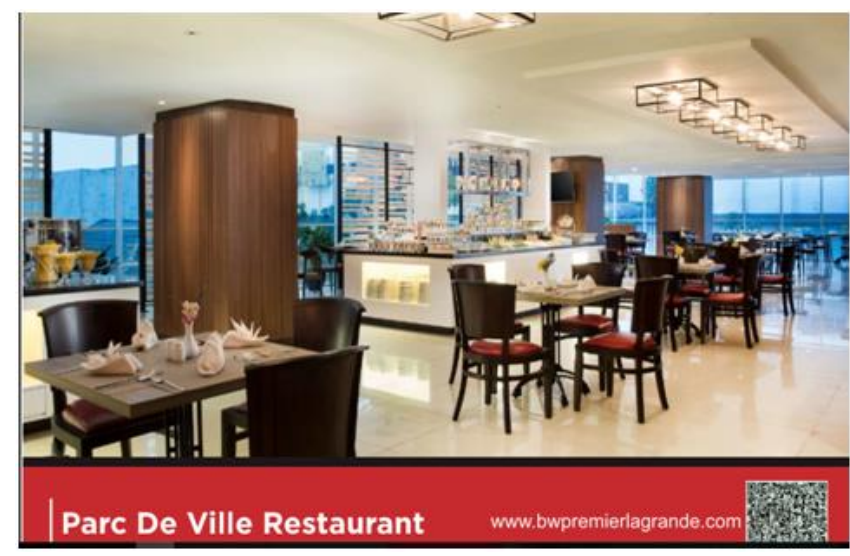

Gambar 5. Tampilan e-brochure pada bagian Restoran beserta informasi alamat website dan barcode

Sumber: (Best Western Premier La Grande Hotel I Bandung, Indonesia, n.d.)

\section{Strategi Marketing dengan Hashtag Instagram}

Teknologi internet telah mampu mengubah wajah dunia. Melalui internet, manusia lebih dimudahkan di segala bidang kehidupan. Hal ini juga diikuti dengan perangkat sebagai kebutuhan primer yaitu smart phone atau gawai. Melalui perangkat genggam ini, dunia seolah terasa dekat dan mampu menciptakan kreativitas serta menjadi media partner di segala bidang kehidupan. Sebagian besar pengguna internet atau sosial media di Indonesia adalah orang yang menggunakan smartphone (telephone pintar). Benda tersebut membuat konektivitas tanpa batas seakan jarak tidak berarti antar penggunanya.

Satu diantara aplikasi yang paling banyak diakses oleh para pengguna internet (netizen) adalah Instagram. Aplikasi instagram merupakan salah satu bentuk media sosial di dunia maya yang penggunanya dapat mengunggah foto, menerapkan filter digital, serta membagikannya ke berbagai jejaring media sosial. Aplikasi instagram memiliki fitur unggulan yaitu hashtag. Penerapan hashtag ini difungsikan untuk mengelompokkan tema atau topik yang spesifik dalam media sosial. Selain itu hashtag juga memudahkan para pengguna internet (netizen) dalam pencarian sesuatu 
yang sedang viral atau pun saling berhubungan di jagat maya. Pada era digital, dengan hashtag konten marketing di media sosial sangat berperan dalam mempromosikan suatu produk. Karena melalui hashtag sebuah tema atau topik dapat digolongkan secara spesifik sehingga orang lain (netizen) atau calon pelanggan bisa menemukan informasi yang disampaikan oleh sebuah artikel dengan hashtag tertentu (Permatasari \& Trijayanto, 2017).

Pengelola Hotel Best Western Premier Bandung melalui humasnya IT memanfatkan hashtag dalam aplikasi instagram, terutama untuk mengenalkan Restorannya (Humas, personal communication, 2019). Sebagian pengunjung restoran disarankan untuk memfoto menu dining kemudian diupload pada instagram dengan hashtag Best Western Premier La Grande Bandung. Strategi ini terbukti efektif untuk mempromosikan restoran Hotel Best Western Premier La Grande Bandung. Dengan hashtag tersebut netizen akan lebih mudah mendapatkan informasi secara cepat jika mencari konten terkait dengan hotel atau restoran. Berikut beberapa hasil hashtag dari beberapa pengunjung restoran Hotel Best Western Premier La Grande Bandung.

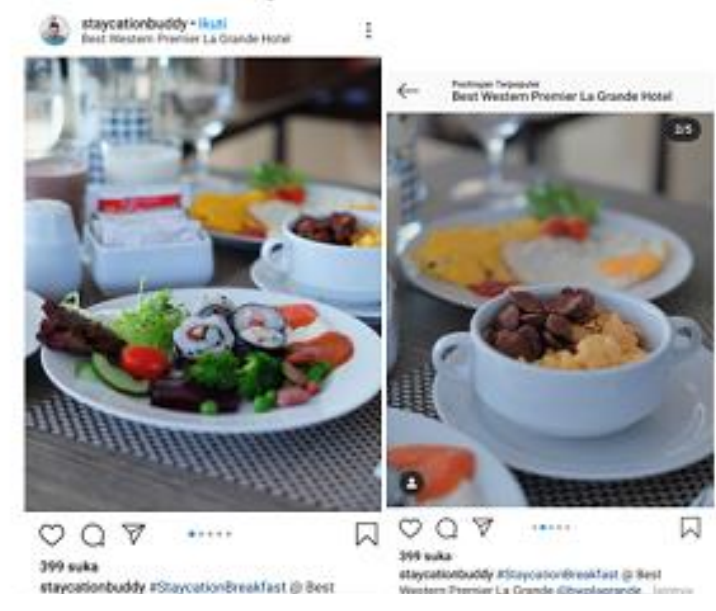

Gambar 6. Menu restoran di Instagram dengan hashtag Best Western Premier La Grande Sumber: Dokumentasi Peneliti, 2020 
Hashtagh di atas sangat membantu dalam pemasaran online terutama pemasaran restoran di Hotel Best Western Premier La Grande Bandung. Selain warga sekitar Bandung Raya, rata-rata pengunjung juga merupakan pelancong yang berasal dari berbagai kota di Indonesia. Para pengunjung yang antusias memposting aktivitas di instagram adalah hasil dari stretegi pengelola hotel khsusunya pihak restoran. Selain berisi gambar atau foto menu, pengunjung juga memposting figure diri bersama menu makanannya di restoran Hotel Best Western Premier La Grande. Berikut beberapa tangkapan foto di instagram yang memuat figur pengunjung bersama menu di restoran tersebut;

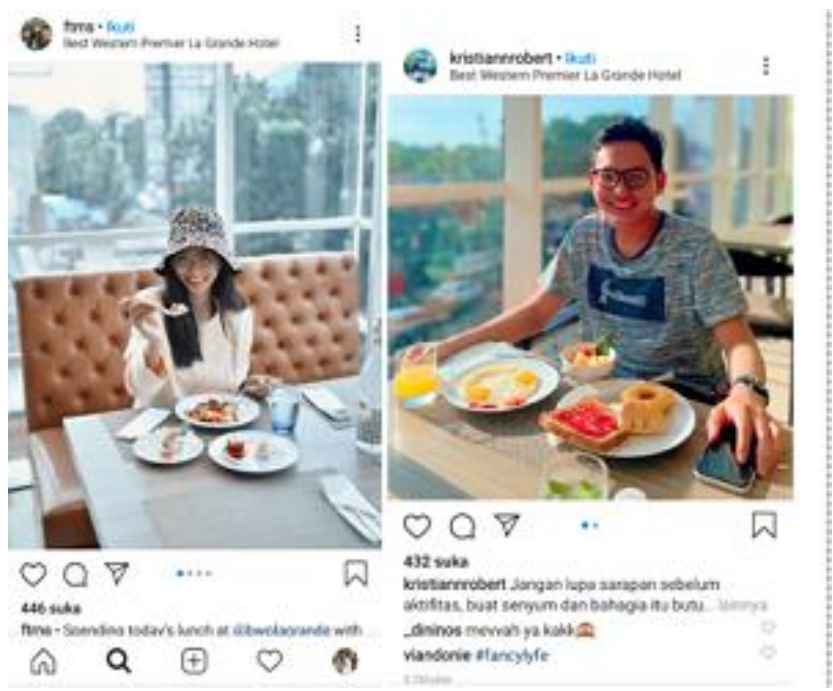

Gambar 7. Foto pengunjung dengan menu restoran di Instagram dengan hashtag

\section{Best Western Premier La Grande di Bandung}

Sumber: Dokumentasi Peneliti, 2020

Motif pengguna Hashtag juga beragam, mulai dari mengikuti trend yang ada, menampilkan fashion yang dipakai, bahkan hanya motif sekedar banyak yang menyukai agar viral di dunia maya. Secara umum metode promosi seperti ini belum banyak digunakan oleh banyak perusahaan, termasuk di bidang kuliner. Padahal dari segi efektifitas dan efisiensi, strategi hashtag instagram terbukti sangat baik dalam 
dunia marketing mengingat penggunanya terus meningkat (Permatasari \& Trijayanto, 2017).

\section{Efektivitas Penerapan Pemasaran Restoran Hotel Best Western La Grande Bandung}

Hasil analisa tentang pemasaran Restoran Hotel Best Western La Grande Bandung yaitu dengan menggunakan pemasaran digital atau online. Pemasarannya menerapkan publikasi dan informasi berbasis digital. Hal tersebut dibuktikan dengan adanya website Hotel Best Westen La Grande Di Bandung, E-brochure, dan pemanfaatan Hashtag instagram. Pada sub bab ini akan di bahas bagaimana metode pemasaran itu diaplikasikan untuk para netizen dan sejauh mana tingkat efektivitas metode pemasaran digital tersebut.

Pemasaran digital dikelola dan dilakukan oleh tim pengelola Humas dari Hotel Best Western La Grande Bandung. Sejak tiga tahun ini, Humas hotel berfokus pada konten digital. Pemasaran dan publikasi hotel didominasi dengan sistem online. Dari tiga tahun penerapan pemasaran digital, ditunjukkan tingkat perubahan yang sangat signifikan. Pengunjung semakin meningkat dan restoran tidak hanya untuk pengunjung yang menginap (wisatawan), namun juga ramai pada saat makan malam (dinner) serta pada acara perayaan tertentu (Humas, personal communication, 2019).

Pemasaran digital ini selalu diupdate setiap saat, bahkan semua transaksi hotel telah dapat diakses secara online. Begitu halnya dengan Restoran, pemesanan menu dan operasional di buka secara online, sehingga memudahkan calon pengunjung dan pemesan. Sejak pandemi Covid-19, hotel sempat mengalami penurunan pengunjung, namun itu tidak berlangung lama. Melalui sistem digital, informasi tentang protokol kesehatan CHSE yang telah ditetapkan pemerintah langsung direspon cepat oleh pengelola Hotel Best Western La Grande Bandung. Selama pandemi informasi terkait hotel selalu diupdate guna memberikan informasi kepada calon pengunjung bahwa hotel dan Restoran Best Western La Grande Bandung telah memenuhi standar kesehatan. Strategi pemasaran digital yang telah diterapkan sejak tiga tahun ini 
meningkatkan produktifitas bagi sumber daya manusia baik di hotel dan di Restoran. Berikut prosentase efektivitas dari strategi pemasaran digital, dengan publikasi menggunakan website, e-brochure dan hashtag instagram.

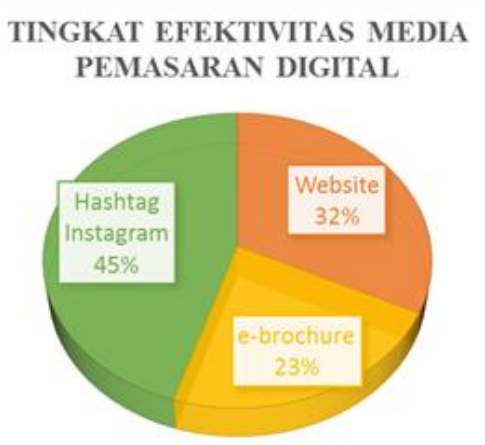

Gambar 8. Prosentase tingkat efektifitas media pemasaran digital Hotel Best Western La Grande Bandung

(Sumber: Tim Humas Hotel Best Western La Grande Bandung yang telah diolah penulis)

Prosentase di atas menunjukan bahwa strategi yang paling efektif untuk pemasaran digital restoran Hotel Best Western La Grande Bandung yaitu hashtag Instagram. Dalam wawancara dengan tim pengelola hotel, sebagian besar pengunjung mengetahui Restoran Hotel Best Western La Grande Bandung dari hashtag instagram yaitu sejumlah 45\%, website $32 \%$ dan e-brochure $23 \%$. Ketiga opsi promosi digital tersebut sebenarnya memberikan informasi yang sama, akan tetapi hashtag Instagram terbukti yang paling efektif karena sangat familiar dan usernya lebih banyak sehingga informasinya lebih cepat tersebar.

Selama ini pengguna media sosial Instagram semakin meningkat. Aplikasi yang mulai ada sejak tahun 2012 hingga saat ini masih sangat digemari oleh para netizen menunjukkan bahwa instagram bukan hanya media sosial untuk mengunggah foto, namun bagi pengelola Hotel Best Western La Grande sebagai 
media pemasaran yang efektif. Hal ini juga dilihat dari penambahan tingkat pengunjung Restoran tersebut.

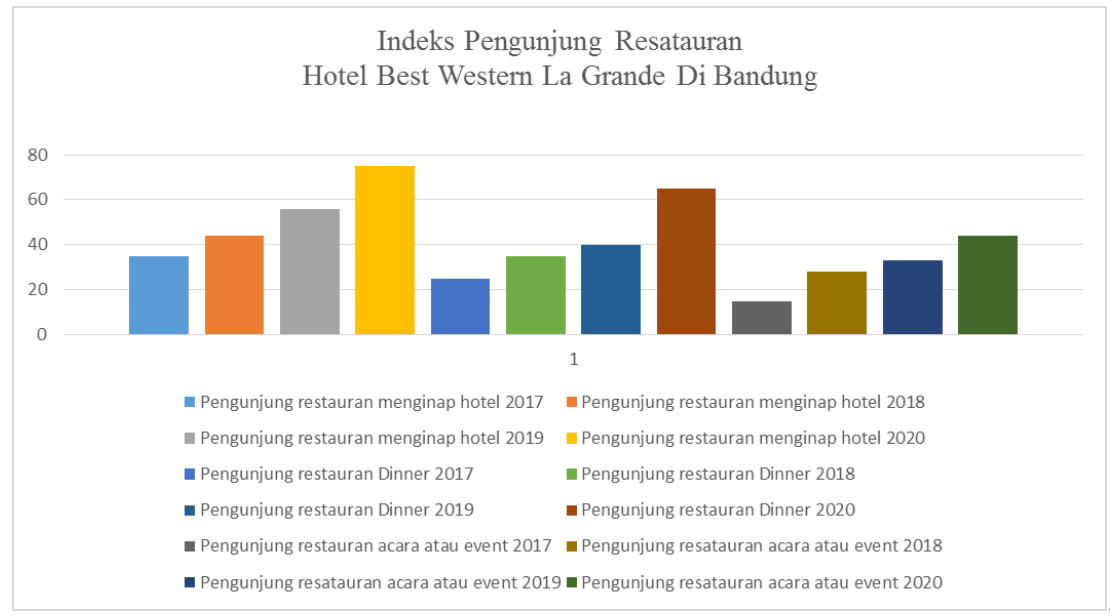

Gambar 9. Indeks peningkatan pengunjung restoran dengan media pemasaran digital di Hotel Best Western La Grande Bandung

(Sumber: Tim Humas Hotel Best Western La Grande Bandung yang telah diolah penulis)

Berdasarkan data indeks pengunjung Restoran kategori menginap di hotel, dinner, dan event atau acara, selama tiga tahun ini mengalami peningkatan. Hal tersebut terjadi karena strategi pemasaran digital dirasa sangat membantu mengenal restoran. Pada titik ini dapat disimpulkan strategi pemasaran digital atau online memiliki tingkat efektivitas yang cukup tinggi dalam memperkenalkan hotel pada umumnya dan terkhusus pada restoran Best Western La Grande.

Berdasarkan fakta di atas terbukti bahwa kreativitas sumber daya restoran khususnya pengelola Humas, efektif dalam me-manage pemasaran. Kreativitas itu terlihat pada strategi hashtag yang berperan besar dalam menaikkan popularitas restoran. Inilah yang kerap disebut peran Human Kreatif dalam sebuah strategi pemasaran. Hotel Best Western La Grande Bandung memiliki human kreatif pada bidang pemasaran digital sehingga dapat dikenal lebih luas, dan pada akhirnya 
bukan hanya saja sebagai fasilitas pendukung namun mampu menjadi sebuah bisnis unggulan dari Hotel Best Western La Grande Bandung.

\section{Kesimpulan dan Saran}

\section{Kesimpulan}

Restoran Hotel Best Western Premier La Grande Bandung melakukan strategi pemasaran yang berlandaskan kreativitas dan menggunakan pendekatan pemasaran digital. Hal ini dapat dilihat dari temuan di lapangan bahwa hotel Best Western Premier La Grande Bandung memiliki website online yang beralamat di http://bwpremierlagrande.com/ dan Digital Brochure atau e-brochure. Kedua konten ini selain mendukung pemasaran hotel, juga mengenalkan Restoran yang dimiliki hotel Best Western Premier La Grande Bandung.

Kreativitas pemasaran tim pengelola Hotel dan Restoran Best Western La Grande tidak hanya berhenti pada website dan e-brochure. Pengelola Hotel Best Western Premier La Grande Bandung melalui humasnya IT memanfatkan hashtag dalam aplikasi Instagram, terutama untuk mengenalkan Restorannya. Strategi ini terbukti sangat efektif untuk pemasaran dan publikasi Restoran Hotel Best Western Premier La Grande. Dengan hashtag ini netizen, calon pengunjung, bahkan pelancong yang sedang berlibur di Bandung lebih mudah mendapatkan informasi secara cepat jika mencari konten terkait dengan Hotel atau Restoran.

Strategi pemasaran digital yang telah diterapkan Restoran Hotel Best Western Premier La Grande Bandung meningkatkan produktifitas bagi sumber daya manusia baik di hotel dan di Restoran. Prosentase efektifitas media pemasaran digital hotel dari hashtag instagram yaitu sejumlah $45 \%$, website $32 \%$, dan e-brochure $23 \%$. Dengan demikian dapat disimpulkan bahwa strategi pemasaran digital atau online melalui media sosial Instagram memiliki tingkat efektivitas yang tinggi dalam 
memperkenalkan Hotel pada umumnya dan terkhusus pada Restoran Hotel Best Western Premiere La Grande Bandung.

\section{Saran}

1. Bagi Pihak Hotel dan Restoran Best Western Premiere La Grande

Seiring dengan gempuran globalisasi kuliner dari berbagai penjuru dunia, penting kiranya pengelolaan restoran juga bersinergi dengan program ekonomi kreatif yang dicanangkan oleh pemerintah. Utamanya untuk pengembangan wisata kuliner berbasis kearifan lokal. Misalnya dalam menu unggulan restoran juga dikembangkan produk-produk makanan khas daerah lokal. Dalam konteks ini selain melestarikan khazanah kekayaan kuliner nusantara, restoran juga sekaligus dapat menjadi corong utama (Brand market) melalui dunia maya.

2. Bagi Perusahaan Bidang Pariwisata dan sejenisnya

Strategy digital seperti yang diterapkan oleh pihak Hotel Best Western Premiere La Grande Bandung perlu diapresiasi dan dijadikan acuan untuk mempromosikan usaha-usaha terkait. Ditambah lagi jika terdapat fasilitas tambahan lainnya, misalnya terdapat wahana outdoor, sauna, taman rekreasi, dll., maka sangat dirasa wajib melakukan publikasi dan pemasaran melaui media sosial Instagram dan semacamnya. Karena secara signifikan akan berbanding lurus jika promosi dilakukan dengan baik dan secara terus menerus.

\section{Ucapan Terima Kasih}

Dalam kesempatan ini penulis sampaikan terima kasih kepada pihak pengelola Hotel Best Western Premiere La Grande Bandung, Tim LP2M Poltekpar Makassar, serta pihak-pihak lain yang telah banyak berkontribusi hingga terselesaikannya riset ini. 


\section{Daftar Pustaka}

Assauri, S. (2011). Manajemen pemasaran.

Best Western Premier La Grande Hotel I Bandung, Indonesia. (n.d.). Retrieved January 29, 2021, from http://bwpremierlagrande.com/

Humas. (2019). Wawancara dengan tim pengelola Humas dari Hotel Best Western La Grande Di Bandung [Personal communication].

Kurniullah, A. Z. (2017). Strategy viral marketing pt. Musim multi media untuk meningkatkan traffic social media fansfage dan brand engagement. Jurnal Visi Komunikasi, 14(2), 169-178.

Moenir, H. D. (2017). Implementasi ASEAN Tourism Strategic Plan 2011-2015 dalam Kebijakan Pariwisata Indonesia di masa Pemerintahan Jokowi. Andalas Journal of International Studies (AJIS), 6(1), 57-78.

Nonto, A. W. (2006). You are what you invest. Majalah Pengusaha, Mei.

Noviantoro, K. M., \& Zurohman, A. (2020). Prospek Pariwisata Syariah (Halal Tourism): Sebuah Tantangan di Era Revolusi Industri 4.0. Equilibrium: Jurnal Ekonomi Syariah, 8(2), 275-296.

Pang, A. (2013). Social media hype in times of crises: Nature, characteristics and impact on organizations. Asia Pacific Media Educator, 23(2), 309-336.

Permatasari, N., \& Trijayanto, D. (2017). Motif Eksistensi melalui penggunaan hashtag (\# OOTD) di media sosial instagram. Promedia, 3(2), 252-273.

Ratna, N. K. (2019). Metodologi penelitian kajian budaya dan ilmu sosial humaniora pada umumnya.

Sukriah, E. (2014). Pariwisata Sebagai Sektor Unggulan Kota Bandung. Jurnal Manajemen Resort Dan Leisure, 11(1), 65-74.

Usmara, A. (2008). Strategi Baru Manajemen Pemasaran, cetakan pertama. Penerbit: Amara Books, Yogyakarta.

Utama, I. G. B. R., \& SE, M. (2015). Pengantar Industri Pariwisata. Deepublish. 


\section{Profil Penulis}

Murdiani Sukarana, SE., MM. Dosen tetap di Prodi Manajemen Tata Hidang Politeknik Pariwisata Negeri Makassar. NIP.196701291998032001, Golongan III/d, Jabatan Lektor, saaat ini sebagai Direktur LSP (Lembaga Sertifikasi Profesi) Pariwisata.

Muhammad Anas, MM. Tenaga Pengajar di Prodi Manajemen Tata Boga Politeknik Pariwisata Makassar. NIP.198206242005021001, dengan jabatan Sekertaris Program Studi MTB. Pernah menjadi Bendahara penerima, aktif menulis dan traveling. 